\title{
High Flux Isotope Reactor Quarterly Report January, February, and March of 1976
}

\author{
R. V. McCord \\ B. L. Corbett
}

\section{OAK RIDGE NATIONAL LABORATORY}




\section{DISCLAIMER}

This report was prepared as an account of work sponsored by an agency of the United States Government. Neither the United States Government nor any agency Thereof, nor any of their employees, makes any warranty, express or implied, or assumes any legal liability or responsibility for the accuracy, completeness, or usefulness of any information, apparatus, product, or process disclosed, or represents that its use would not infringe privately owned rights. Reference herein to any specific commercial product, process, or service by trade name, trademark, manufacturer, or otherwise does not necessarily constitute or imply its endorsement, recommendation, or favoring by the United States Government or any agency thereof. The views and opinions of authors expressed herein do not necessarily state or reflect those of the United States Government or any agency thereof. 


\section{DISCLAIMER}

Portions of this document may be illegible in electronic image products. Images are produced from the best available original document. 
Printed in the United States of America. Available from National Technical Information Service

U.S. Department of Commerce

5285 Port Royal Road, Springfield, Virginia 22161

Price: Printed Copy $\$ 3.50$; Microfiche $\$ 2.25$

This report was prepared as an account of work sponsored by the United States Government. Neither the United States nor the Energy Research and Development Administration/United States Nuclear Regulatory Commission, nor any of their employees, nor any of their contractors, subcontractors, or their employees, makes any warranty, express or implied, or assumes any legal liability or responsibility for the accuracy, completeness or usefulness of any information, apparatus, product or process disclosed, or represents that its use would not infringe privately owned rights. 
Contract No. W-7405-eng-26

Operations Division

HIGH FLUX ISOTOPE REACTOR QUARTERLY REPORT JANUARY, FEBRUARY, AND MARCH OF 1976

R. V. McCord

B. L. Corbett

\section{JULY 1976}

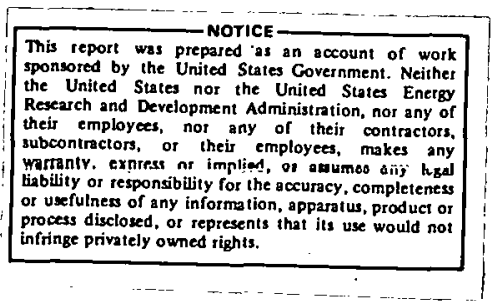

NOTICE This document contains information of a preliminary nature and was prepared primarlly for internal use at the Oak Ridge National Laboratory. It is sublect to revision or correction and thereforo does not represent a final report.

OAK RIDGE NATIONAL LABORATORY

Oak Ridge, Tennessee 37830

operated by

INION CARBIDE CORPORATION

for the

ENERGY RESEARCH AND DEVELOPMENT ADMINISTRATION 


\section{THIS PAGE}

\section{WAS INTENTIONALLY LEFT BLANK}


CONTENTS

Page

SUMMARY . . . . . . . . . . . . . . • . . . . . . . 1

OPERATIONS :............................. 1

SHUTDOWNS . . . . . . . . . . . . . . . . . . . . . 2

OPERATIONAL NOTES AND SPECIAL TESTS ................ 3

Control Plate Bearing Test ................. . 3

Plant MaINTENANCE .......................... . . . 3

INSTRUMENTATION AND CONTROLS . . . . . . . . . . . . . 3

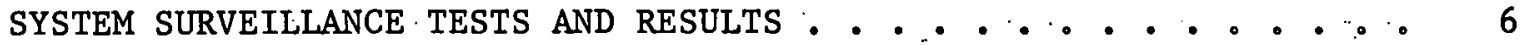

Vessel Head Studs . . . . . . . . . . . . . . 6

Semiannual Reactor-Component Inspection . .......... 6

Stack Filters . . . . . . . . . . ........ 6

REACTOR DESIGN CHANGES . . . . . . . . . . . . . . 8

REACTOR EXPERIMENTS . . . . . . . . . . . . . . 8

Experimental Facilities . . . . . . . . . . . . . 8

HFIR Target Loading . . . . . . . . . . . . . . 9

DISTRIBUTION . . . . . . . . . . . . . . . . 15 


\section{SUMMARY}

Routine reactor operation with only three end-of-cycle shutdowns this quarter resulted in an on-stream time of $95.0 \%$. The semiannual reactor component inspection was completed, and the control plates were changed.

\section{OPERATIONS}

Basic operating data for the quarter are listed in Table 1 :

Table 1. HFIR Basic Operating Data

(January 1, 1976 through March 31, 1976)

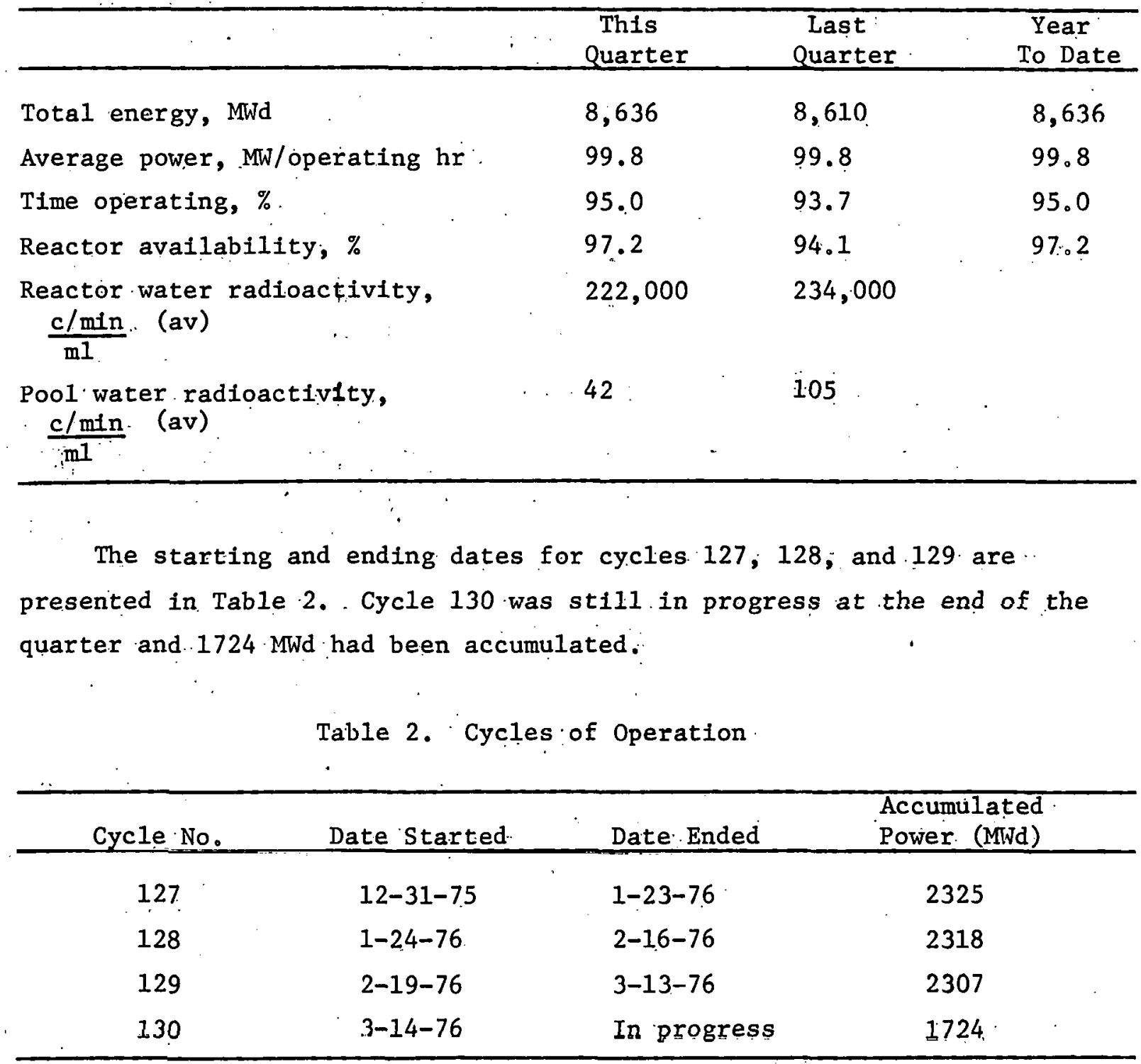


The status of the HFIR fuel and control-plate inventory is indicated in Table 3 。

Table 3。 HFIR Material Inventory.

\begin{tabular}{|c|c|c|}
\hline Item & $\begin{array}{c}\text { This } \\
\text { Quarter }\end{array}$ & $\begin{array}{c}\text { Last } \\
\text { Quarter }\end{array}$ \\
\hline New fuel elements placed in service & 3 & 4 \\
\hline New fuel elements available for use & 47 & 45 \\
\hline Spent fuel elements on hand. & 12 & $\underline{9}$ \\
\hline Spent fuel elements shipped. & 0 & 8 \\
\hline New sets of shim plates placed in service & 0 & 1 \\
\hline New sets of shim plates available for use & 2 & 2 \\
\hline
\end{tabular}

\section{SHUTDOWNS}

There were three end-of-cycle shutdowns this quarter for a total downtime of 108.216 hrs. Table 4 gives further details of the shutdowns.

Table 4; Description of HFIR Shutdowns :

\begin{tabular}{|c|c|c|}
\hline Date & $\begin{array}{c}\text { Downtime } \\
\text { (hr) }\end{array}$ & Remarks \\
\hline $1-23-76$ & 13.000 & $\begin{array}{l}\text { Fuel cycle } 127 \text { was completed at } 9: 00 \text { p.m. A total } \\
\text { power generation of } 2325 \text { MWd was obtained on fuel } \\
\text { elements } 123-0 \text { and } 123-1 \text {. }\end{array}$ \\
\hline $2-16-76$ & 64.583 & 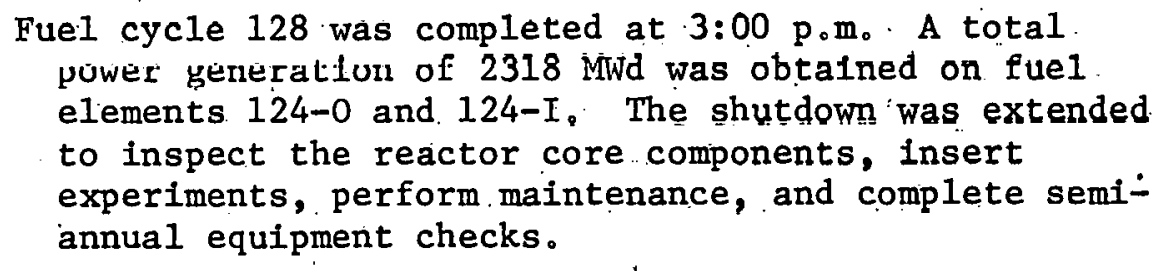 \\
\hline $\begin{array}{c}3-1-3-76 \\
.\end{array}$ & 30.633 & $\begin{array}{l}\text { Fuel cycle-129. was completed at } 10: 54 \mathrm{a}_{\circ} \mathrm{m}_{\text {. A total }} \text { A tot } \\
\text { power generation of } 2307 \text { MWd was obtained on fuel } \\
\text { elements } 125-0 \text { and } 125-\mathrm{I} \text {. The shutdown was extended } \\
\text { for some work on experiments. }\end{array}$ \\
\hline
\end{tabular}


OPERATIONAL NOTES AND SPECIAL TESTS

Control Plate Bearing Test

A test of four sleeve-type journal bearings was completed this quarter. These journal bearings were mounted on a control plate that was installed in the reactor at the start of fuel cycle 125. This plate was removed from the reactor at the end of cycle 128 .

Based on a previous series of rod drops with journal bearings, it was expected that the time-of-flight of the plate with the experimental bearings would be $6-7 \%$ longer than a normal plate. Time-of-flight measurements, made during the course of this test showed that the experimental plate was taking an average 12-15\% longer than a normal plate: Although this was still well within the operating limits, the discrepancy between the initial test and the in-reactor run was disturbing.

When the journal bearings were removed from the plate for examination at the completion of the test, flat spots were found on the two bearings mounted at the top of the control plate. This indicated that these bearings were not turning as the plate moved in the reactor. There was no obvious explanation of this sticking phenomena on the top bearings since the bottom bearings appeared to have rolled and exhibited the expected amount of wear.

To continue the study of journal-bearing performance in the reactor., four more bearings will be fabricated to slightly different specifications. Clearances between the rotating parts of the bearing will be increased slightly, and the surface finish of mating components will be made smoother. Another in-reactor test will be conducted.

\section{PLANT MAINTENANCE}

Maintenance and changes in the various process systems are listed in Table 5.

INSTRUMENTATION AND: CONTROLS

Maintenance and changes in the various instrumentation systems are listed in Table 6 . 
Table 5 . Process System - Maintenance and Charges

\begin{tabular}{|c|c|c|}
\hline Date & Component & Remarks \\
\hline & & Primary System \\
\hline $1-2-76$ & Letdown valve & $\begin{array}{l}\text { The misoperating letdown valve in cell } 110 \text { was replaced with a spare } \\
\text { valve. }\end{array}$ \\
\hline $2-17-76$ & Drive rod & $\begin{array}{l}\text { The drive rod assembly for the No. } 4 \text { safety plate was changed out as } \\
\text { part of the preventive maintenance program. }\end{array}$ \\
\hline $2-17-76$ & Letdown valve & $\begin{array}{l}\text { The letdown valve in cell } 112 \text { was found to be inoperative, and it was } \\
\text { replaced with a spare valve. } \\
\text { Secondary system }\end{array}$ \\
\hline $2-2-76$ & Circulating pump & $\begin{array}{l}\text { The auxiliary secondary coolant circulating punp, PU-14, was returned } \\
\text { to. service. The impeller shaft coupling broke on this pump in June, } \\
\text { 19.75. }\end{array}$ \\
\hline $2-23-76$ & Cooling tower fan & $\begin{array}{l}\text { Cooling tower fan assembly } \mathrm{FN}-4 \mathrm{~A} 2 \text { was reflaced with a rebuilt unit. } \\
\text { The gearbox seals had developed oil leaks. }\end{array}$ \\
\hline \multirow[t]{2}{*}{$3-20-76$} & Cooling tower fan & $\begin{array}{l}\text { Intermittent arcing and overheating occurred in the circuit breaker of } \\
\text { fan FN-4A2. Damaged components. were replaced, and all connections } \\
\text { were tightened. }\end{array}$ \\
\hline & & Miscellaneous \\
\hline $1-21-76$ & Nitric acid punp & $\begin{array}{l}\text { The north nitric acid pump. in the primary } \mathrm{pH} \text { control system was replaced } \\
\text { because of leaking seals. }\end{array}$ \\
\hline $1-24-76$ & Battery charger & $\begin{array}{l}\text { The battery charger for pony motor PU-1H tripped out of service. A fuse } \\
\text { had blown in its control circuit. }\end{array}$ \\
\hline $3-13-76$ & Battery charger & $\begin{array}{l}\text { The battery charger for pony motor } \mathrm{PU}-1 \mathrm{H} \text { blew a control fuse when } \mathrm{AC} \\
\text { power.was turned on following a reliability test. The charger failed } \\
\text { again the next day during startup checks, and all three fuses were. } \\
\text { replaced. }\end{array}$ \\
\hline
\end{tabular}


Table 6. Instrumentation - Maintenance and Changes

\begin{tabular}{|c|c|c|}
\hline Date & Component & Remarks \\
\hline & - & Safety System \\
\hline $2-19-76$ & Signal convertẹ & $\begin{array}{l}\text { The dual signal converter in channel No: } 1 \text { was replaced because the reset } \\
\text { flux readout was too high. } \\
\text { Servo System }\end{array}$ \\
\hline $2-20-76$ & Signal converter & $\begin{array}{l}\text { Misoperation of the regulating rod position recorder was corrected by the } \\
\text { repair of its dual signal converter. }\end{array}$ \\
\hline $3-26-76$ & Motor & $\begin{array}{l}\text { A new type servo motor was installed in the No. } 1 \text { channel. The motor in } \\
\text { this position developed intermittent sticking problems, and no more } \\
\text { motors of the original type are aváilable. } \\
\text { Miscellaneous }\end{array}$ \\
\hline $1-2-76$ & Relays & $\begin{array}{l}\text { At least two of the three relays in the main flow sensing matrix of the } \\
\text { hydraulic tube control system failed. They were replaced. }\end{array}$ \\
\hline $1-7-76$ & Power indicator & $\begin{array}{l}\text { A new servo motor was installed in the long-scale digital-log power } \\
\text { indicating instrument. }\end{array}$ \\
\hline
\end{tabular}


SYSTEM SURVEILLANCE TESTS AND RESULTS

\section{Vesse1 Head Studs}

The accumulated number of tensioning cycles on the reactor vessel head studs is presented in Table 7. These studs were designed for a fatigue life of 40 cycles loading due to tensioning of the bolts and.730 full-pressure (1000 psig) cycles. Installation of new reactor vessel head studs was completed in June, 1972. The numbers in Table 7 represent the maximum cycles to. which any new stud has been exposed.

Tulble 7. Veșsel Head 3tud-Tensioning Cycles

\begin{tabular}{|c|c|c|c|c|}
\hline & & $\begin{array}{c}\text { This } \\
\text { Quarter } \\
\end{array}$ & $\begin{array}{c}\text { Last } \\
\text { Quarter }\end{array}$ & $\begin{array}{l}\text { Total } \\
\text { To Date }\end{array}$ \\
\hline Head bolt & tensioned & 0 & 0 & 6 \\
\hline 1500 psig & 1 & & & 0 \\
\hline 950 psig & . & 0 & 0 & 7 \\
\hline 650 psig & & 3 & 4 & 101 \\
\hline
\end{tabular}

Semiannual Keactor-Component linspection

At the end of fuel cycle 128, the semiannual reactor-component inspection was made. l'he shroud flange, fuel grid, and control plates were removed from the vessel: The components which remalned in the vessel--upper and lower tracks, beryllium, beam tubes, and support pedestals--were inspected. No component abnormalities were detected.

\section{Stack Filters}

Stack filtering systems in the special building hot exhaust (SBHE) and hot off-gas (HOG) systems were tested for particulate removal efficiency。 Results of the most recent tests are tabulated in Table 8 . 
Table 8. Particulate and Iodine Removal Efficiency

\begin{tabular}{|c|c|c|c|c|c|c|c|c|c|c|c|c|c|}
\hline \multirow[b]{3}{*}{ Pilter Bank } & \multicolumn{4}{|c|}{ Methy 1 Iodide } & \multicolumn{4}{|c|}{ Elemental Iodine } & \multirow{3}{*}{$\begin{array}{c}\text { Filter } \\
\text { Position } \\
\end{array}$} & \multicolumn{4}{|c|}{ Particulate Retention } \\
\hline & \multicolumn{2}{|c|}{ Last Test } & \multicolumn{2}{|c|}{ Previous Test } & \multicolumn{2}{|c|}{ Last Test } & \multicolumn{2}{|c|}{ Previous Test } & & \multicolumn{2}{|c|}{ Last Test } & \multicolumn{2}{|c|}{ Previous Test } \\
\hline & Date & Eff., $\bar{Z}$ & Date & Eff., 7 & Date & Eff., 7 & Date & Eff., $\bar{x}$ & & Date & Eff., $\chi$ & Date & Eff., $\bar{X}$ \\
\hline \multirow[t]{2}{*}{ SBHE, west } & $10-23-75$ & 75 & $4-15-75$ & 88 & $9-8-75$ & 99.90 & $3-18-75$ & 99.93 & South & $3-26-76$ & 99.980 & 9-26-75. & 99.9 .96 \\
\hline & & & & & & & . & & North & $3-26-76$ & $99: 000 *$ & $9-26-75$ & 99.997 \\
\hline \multirow[t]{2}{*}{ SBHE, center } & $10-29-75$ & 88 & $4-24-75$ & 90 & $9-11-75$ & 99.97 & $3-20-75$ & 99.99 & South & $3-26-76$ & 99.988 & $9-26-75$ & 99.995 \\
\hline & & & & & & & & & North & $3-26-76$ & 99.960 & $9-26-75$ & 99.958 \\
\hline \multirow[t]{2}{*}{$S B H E$, east } & $10-28-75$ & 59 & $4-17-75$ & 42 & $10-9-75$ & 99.91 & $3-19-75$ & 99.93 & South & $3-26-76$ & 99.956 & $9-26-75$ & 99.992 \\
\hline & & & & & & & & & North & $3-26-76$ & $99.930 *$ & $9-26-75$ & 99.960 \\
\hline HoG, west & $10-30-75$ & 90 & $4-8-75$ & 77 & $10-20-75$ & 99.98 & $3-26-75$ & 99.97 & & & & & \\
\hline HOG, center & $11-5-75$ & 44 & $4-10-75$ & 99.52 & $10-14-75$ & 99.99 & $3-26-75$ & 99.99 & & & : & & \\
\hline HOG, east & $11-4-75$ & 92 & $4-2-75$ & $49^{\circ}$ & $10-15-75$ & 99.99 & $3-26-75$ & 99.94 & & & & & \\
\hline
\end{tabular}

*F1lter were replaced. 


\section{REACTOR DESIGN CHANGES}

Mechanical design change memoranda which describe work completed this quarter are tabulated in Table 9 .

Table 9. Mechanical Design Change Memoranda

\begin{tabular}{|c|c|c|}
\hline $\begin{array}{l}\text { Memo } \\
\text { No: }\end{array}$ & Subject & Genera1 Description \\
\hline 50 & Control plate bearings & $\begin{array}{l}\text { The ball bearings used on the HFIR control } \\
\text { plates have been discontinued as a stan- } \\
\text { dard production ftem. sperially ordered. } \\
\text { replacement bearinge will incorporate two } \\
\text { improvements: (1) the race diameter has } \\
\text { been increased to eliminate the instal- } \\
\text { lation of the "tire". presently required; } \\
\text { and (2) a split race which holds the balls } \\
\text { more securely has been incorporated. }\end{array}$ \\
\hline 51 & $\begin{array}{l}\text { Pool bypass filter } \\
\text { drain line rerouting }\end{array}$ & $\begin{array}{l}\text { Chemicals used to clean the pool bypass } \\
\text { filter are flushed into an ILW drain line. } \\
\text { occasionally these chemicals are forced } \\
\text { into the primary head tank through an } \\
\text { overflow line. To prevent this happening, } \\
\text { the pool bypass filter drain line will be } \\
\text { rerouted from the ILW to the PWD system. }\end{array}$ \\
\hline
\end{tabular}

REACTOR EXPERIMENTS

Experimental Facilities

Usage of the various HFIR experiment facilities is tabulated in Table 10。 
Table 10. Experiment Facility Usage

\begin{tabular}{|c|c|c|}
\hline Facility & Description & Division \\
\hline $\mathrm{RB}-1$ & Isotope production. & Operations \\
\hline $\mathrm{RB}-2$ & Isotope production & Operations \\
\hline$R B-3$ & Isotope production & Operations \\
\hline $\mathrm{RB}-4$ & HFIR tensile specimens & Operations \\
\hline $\mathrm{RB}-5$ & HTGR fuel irradiations & Reactor. \\
\hline $\mathrm{RB}-6$ & Isotope production & Operations \\
\hline $\mathrm{RB}-7$. & HTGR fuel irradiations & Reactor \\
\hline $\mathrm{RB}-8$ & Isotope production & Operations \\
\hline $\mathrm{CR}-1$ & Isotope production & Operations \\
\hline $\mathrm{CR}-2$ & Isotope production & Operations \\
\hline $\mathrm{CR}-3$ & Californium production & Chemical l'echnology \\
\hline $\mathrm{CR}-4$ & Californium production & Chemical Technology. \\
\hline $\mathrm{CR}-5$ & Isotope production & Operations \\
\hline $\mathrm{CR}-6$ & Isotope production & Operations \\
\hline $\mathrm{CR}-7$ & Isotope production & Operations \\
\hline $\mathrm{CR}-8$ & Isotope production. & Operations \\
\hline $\mathrm{VXF}-1$ & HFIR corrosion specimen & Operations \\
\hline $\mathrm{VXF}-7$ & Pneumatic tube. & Analytical Chemistry \\
\hline $\mathrm{EF}-2$ & Noise analysis studies & $\begin{array}{l}\text { Instrumentation and Controls } \\
\text { and Operations }\end{array}$ \\
\hline $\mathrm{HB}-1$ & Neutron diffractometer & Solid State \\
\hline $\mathrm{HB}-2$ & Neutron diffractometer & Chemistry \\
\hline $\mathrm{HB}-3$ & Neutron diffractometer. & Solid State \\
\hline $\mathrm{HB}-4$ & Neutron diffractometer & Solid State \\
\hline
\end{tabular}

HFIR Target Loading

A description of the HFIR target loading for each of the operating cycles this quarter is presented in Figures 1, 2, 3, and 4 . 


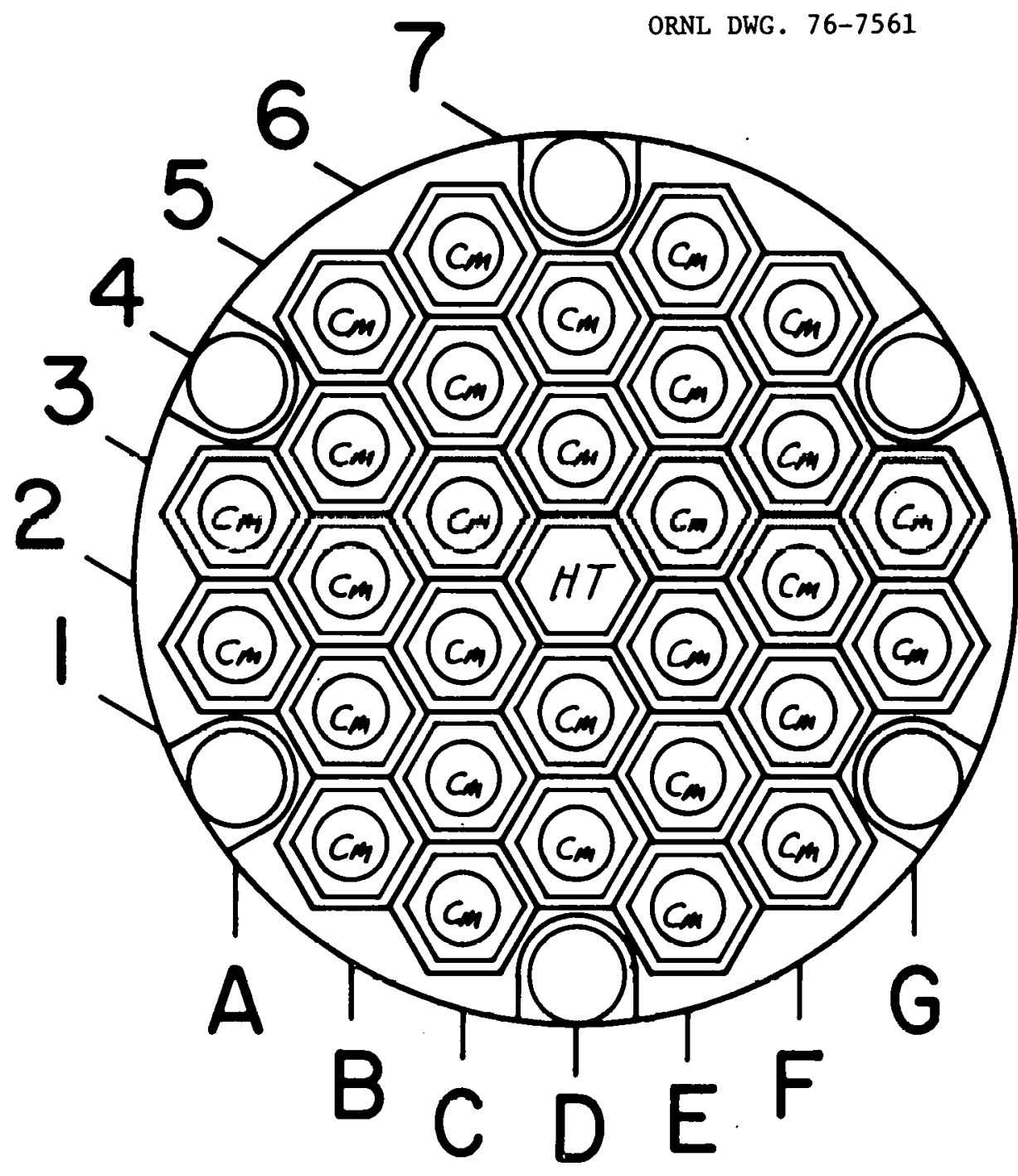

TARGET TYPE

PLUTONIUM (Pu)

CURIUM (Cm)

STAINLESS STEEL (SST)

GRAPHITE (C)

ALUMINUM (AI)

HYDRAULIC TUBE (HT)
NUMBER

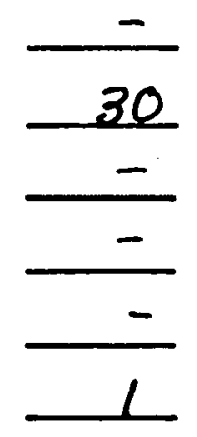

Fig. 1. HFIR Target Loading for Cycle 127 - December 31, 1975 


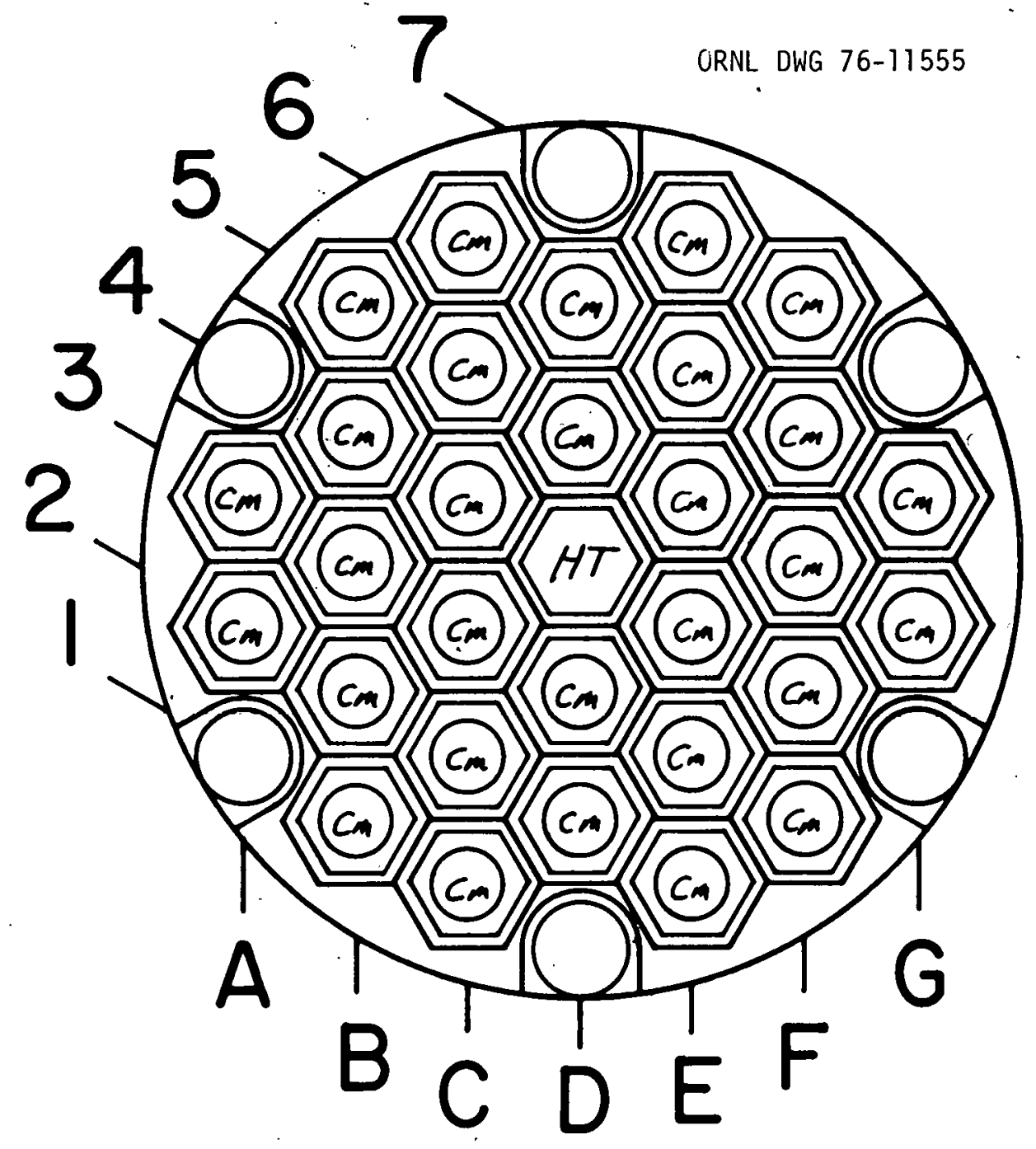

TARGET TYPE

PLUTONIUM (PU)

CURIUM (Cm)

STAINLESS STEEL (SST)

GRAPHITE (C)

ALUMINUM (AI)

HYDRAULIC TUBE (HT)
NUMBER

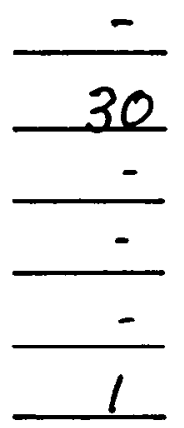

Fig. 2. HFIR Target Loading for Cycle 128 - January 24, 1976 


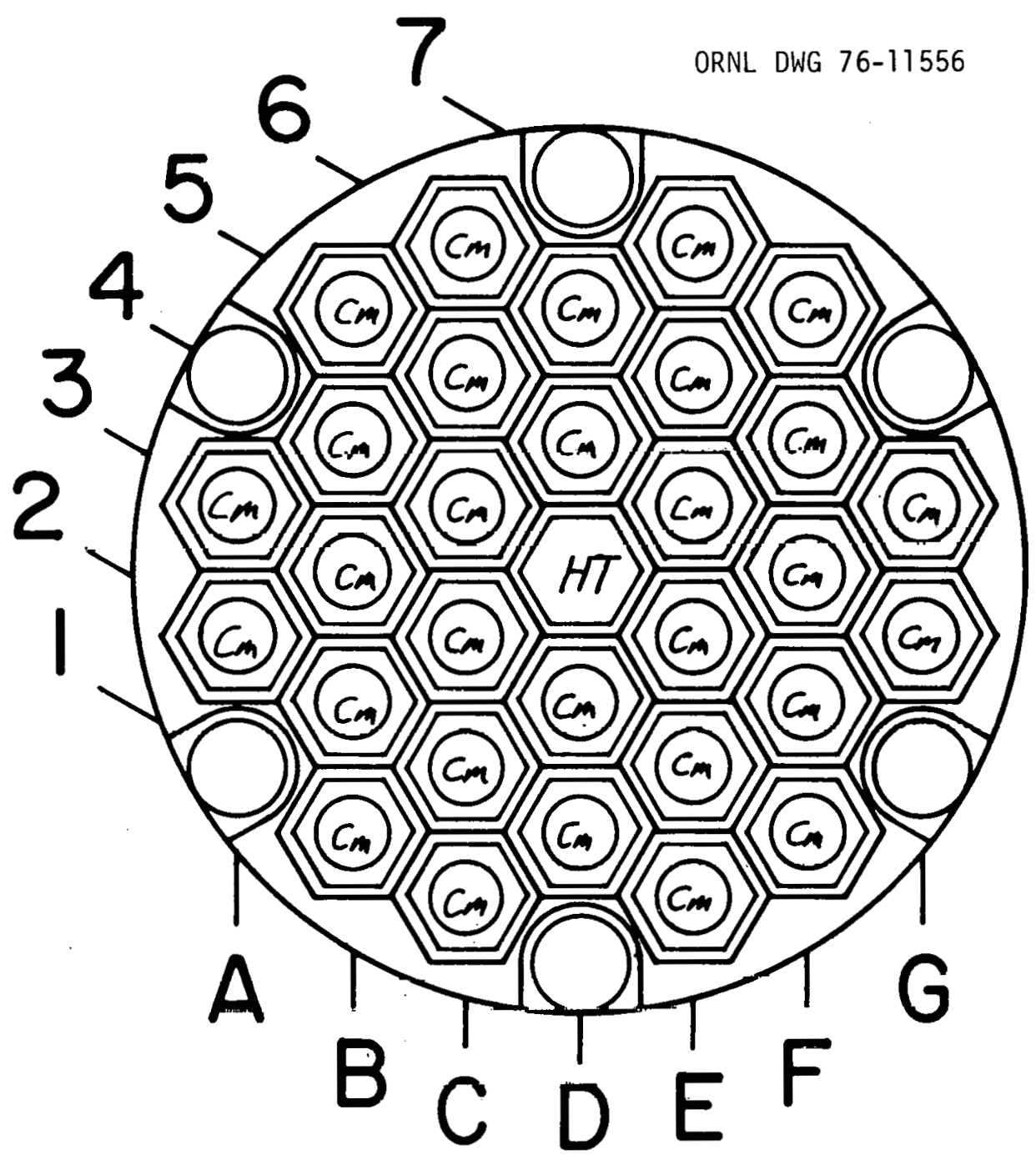

TARGET TYPE

PLUTONIUM (Pu)

CURIUM (Cm)

STAINLESS STEEL (SST)

GRAPHITE (C)

ALUMINUM (AI)

HYDRAULIC TUBE (HT)
NUMBER

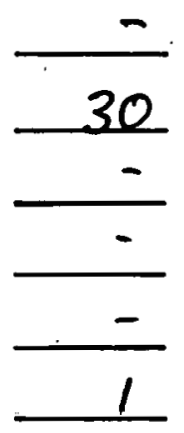

Fig: 3. HFIR Target Loading for Cycle 129 - February 19, 1976 


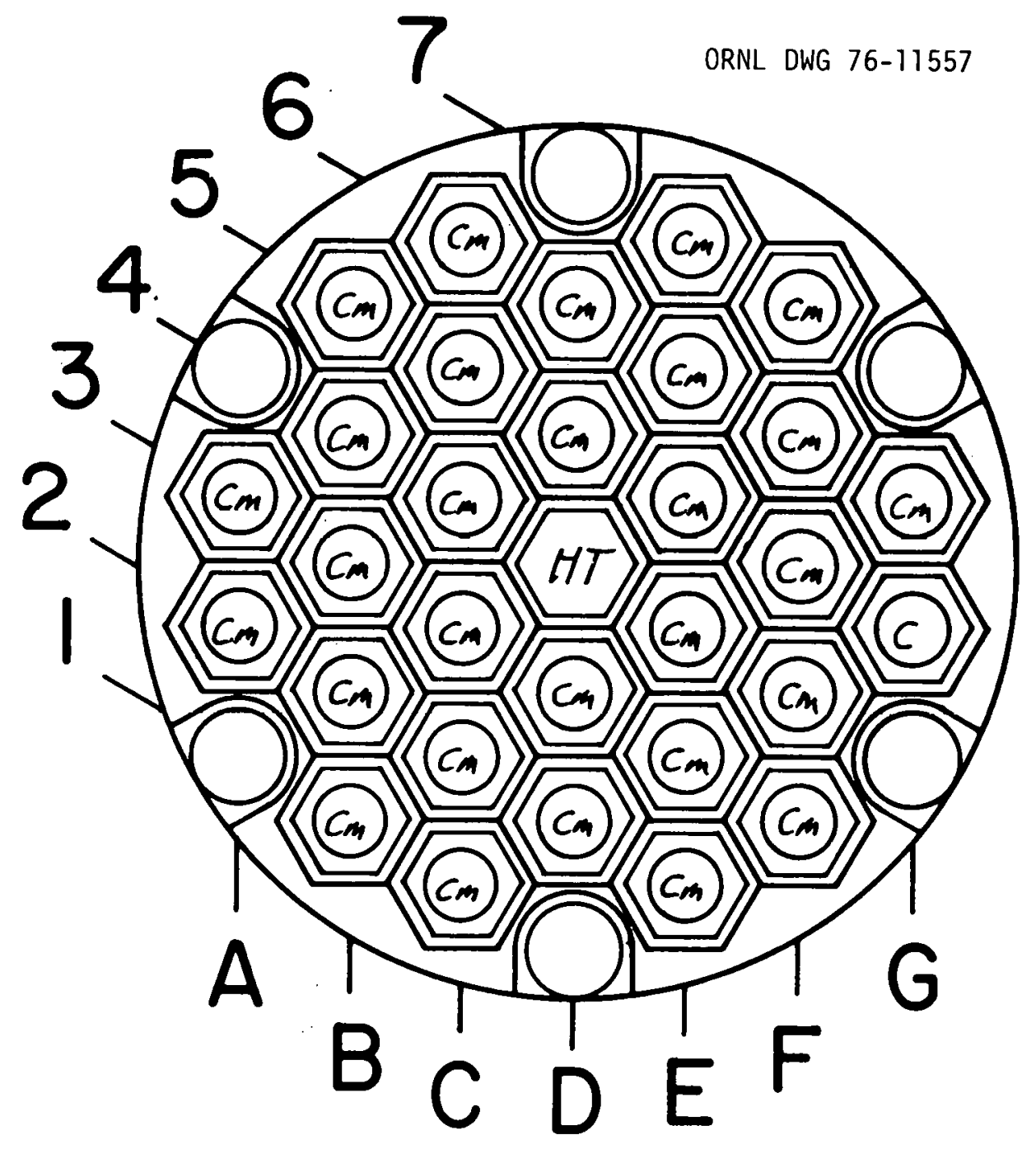

TARGET TYPE

NUMBER

PLUTONIUM (Pu)

CURIUM (Cm)

STAINLESS STEEL (SST)

GRAPHITE (C)

ALUMINUM (AI)

HYDRAULIC TUBE (HT)

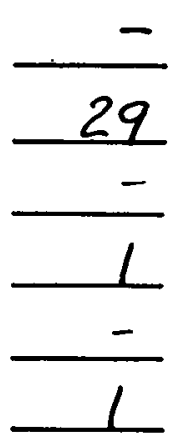

Fig. 4. HFIR Target Loading for Cycle 130 - March 14, 1976 


\section{THIS PAGE WAS INTENTIONALLY LEFT BLANK}


ORNL/TM-5541

\section{INTERNAL DISTRIBUTION}

1. G. M. Adamson

2. Ro G. Affel

3. J. L. Anderson

4. D. S。 Asquith

5。 Ko S。 Belitz

6. J。 E: Bigelow

7. D. S. Billington

8. F. T. Binford

9. H. Blauer

10。 C. D. Cagle

11. W. Ro Casto

12. R. D。 Cheverton

13. T. E. Cole

14. J. A. Conlin

15-16. B. L. Corbett

17. J. A. Cox

18. W. H。 Culbert

19. F。 L. Culler

20. S. Jo Ditto

21. G。 J. Dixon

22. Ko Farrell

23. A. P. Fraas

24. E。 D. Gupton

25. T。P。Hamrick

26. V. 0. Haynes

27. C. H. Helton

28. S . S. Hurt, III

29. E。 B. Johnson

30. S. I. Kaplan

31. Oo L. Keller

32. E. M. King
33. H. V. Klaus

34. R。 W. Knight

35. W. C. Koehler

36: E。 Lamb

37. H. A。 Levy

38. J o Lewin

39-44. R. V. McCord

45. Jo R。 McGuffey

46. H. A. McLain

47. J。 R。 McWherter

48. J. M. Miller

49. L. C. Oakes

50. H. Postma

51. K. Ho Poteet

52. M. E。 Ramsey

53. R. L. Scott

54. W. H. Sides

55. T。M. Sims

56. Mo J. Skinner

57. J. H. Swanks

58. Jo. Ro Thomas

59. D. B. Trauger

60. J。R. Weir

61. K. W. West

62. $\mathrm{M}_{\circ} \cdot \mathrm{K}$. Wilkinson

63. E. J. Witkowski

64-65. Central Research Library

66. Document Reference Section

67-68. Laboratory Records Department

69. Laboratory Records, ORNL R.C.

EXTERNAL DISTRIBUTION

70-96. Technical Information Center, Oak Ridge

97-98. M. B. Biles, ERDA Washington

99. K。 J。 Bobin, Belgium

100. J. L. Burnett, ERDA Washington

101. II. N. Culver, ERDA

102. M. Jacquemain, France

103. G. L。 Rogosa, ERDA Washington

104. Research and Technical Support Division, ORO 